\title{
SPECIALIST SERVICE IN LIVER TRANSPLANT IN A UNIVERSITY HOSPITAL: A CASE STUDY
}

\author{
Sílvia Ferrazzo ${ }^{1}$, Mara Ambrosina de Oliveira Vargas², Diana Coelho Gomes³, Francine Lima Gelbcke4, \\ Karina Silveira de Almeida Hammerschimidt ${ }^{5}$, Camila Ferrazzo Lodeyro ${ }^{6}$
}

${ }^{1}$ M.Sc. in Nursing. Florianópolis, Santa Catarina, Brasil. E-mail: silvia.ferrazzo@gmail.com

${ }^{2}$ Ph.D. in Nursing. Professor, Undergraduate and Post-Graduate Nursing course (PEN) in the Universidade Federal de Santa Catarina (UFSC). Florianópolis, Santa Catarina, Brasil. E-mail: ambrosina.mara@ufsc.br

${ }^{3}$ M.Sc. in Nursing. Florianópolis, Santa Catarina, Brasil. E-mail: dianacoelhog@yahoo.com.br

${ }^{4}$ Ph.D. in Nursing. Professor, Undergraduate and Post-Graduate Course in UFSC. Florianópolis, Santa Catarina, Brasil. E-mail: fgelbcke@ccs.ufsc.br

${ }^{5}$ Ph.D. in Nursing. Professor, undergraduate and PEN/UFSC. Florianópolis, Santa Catarina, Brasil. E-mail: karina.h@ufsc.br

${ }^{6}$ Biologist Specialist in Expertise and Environmental Auditing. Florianópolis, Santa Catarina, Brasil. E-mail: milaferrazzo@gmail.com

\begin{abstract}
Objective: was to describe the flow of a specialist service in the care of liver transplant in a university hospital.

Method: a qualitative research in the form of a case study, performed in a transplant service in southern Brazil. Data collection occurred from November 2013 to February 2014 through the triangulation of data, document analysis, structured interviews with 11 professional and semi direct observations interviews. Data analysis was performed by analysis of thematic content.

Results: describes the flow of service and revealed the involvement of a multidisciplinary team in a cohesive manner, with competence recognized by patients and other sectors of the institution and structural deficiencies in care service for immunosuppressed patients.

Conclusion: it was found that there is a need for studies that address the structures of care in liver transplantation services and to evaluate the impact of the quality of the life expectancy and proper recovery of persons undergoing liver transplantation.

DESCRIPTORS: Liver transplantation. Patient care team. Workflow.

\section{SERVIÇO ESPECIALIZADO EM TRANSPLANTE HEPÁTICO EM UM HOSPITAL UNIVERSITÁRIO: UM ESTUDO DE CASO}

\section{RESUMO}

Objetivo: descrever o fluxo do serviço especializado no atendimento em transplante hepático de um hospital universitário.

Método: pesquisa qualitativa, do tipo estudo de caso, realizada em um serviço de transplante do sul do Brasil. A coleta dos dados ocorreu no período de novembro de 2013 a fevereiro de 2014 por meio da triangulação dos dados, análise documental, entrevistas semiestruturadas com 11 profissionais e observações diretas. A análise de dados foi realizada pela análise de conteúdo temática.

Resultados: os achados descreveram o fluxo do serviço e revelaram a atuação de uma equipe multidisciplinar de forma coesa, com competência reconhecida por pacientes e demais setores da instituição, carências estruturais no serviço para atendimento de pacientes imunossuprimidos.

Conclusão: constatou-se que há necessidade de estudos que abordem as estruturas dos atendimentos em serviços de transplante de fígado e avaliem o impacto da qualidade dessas na expectativa de vida e na adequada recuperação das pessoas submetidas ao transplante hepático. DESCRITORES: Transplante de fígado. Equipe de assistência ao paciente. Fluxo de trabalho. 


\title{
SERVICIO ESPECIALIZADO DE TRASPLANTE DE HÍGADO EN UN HOSPITAL UNIVERSITARIO: UN ESTUDIO DE CASO
}

\begin{abstract}
RESUMEN
Objetivo: describir el flujo de servicio que se especializa en el cuidado de trasplante de hígado.

Método: la investigación cualitativa, estudio de caso, realizado en un servicio de trasplante en un hospital universitario en el sur de Brasil. La recolección de datos se produjo de la Investigación, a partir de noviembre 2013 a febrero 2014 a través de la triangulación de datos, análisis de documentos, entrevistas estructuradas con 11 profesionales y semi observaciones entrevistas directas. El análisis de datos se realizó mediante el análisis de contenido temático.

Resultados: describir el flujo de servicio y revelaron la participación de un equipo multidisciplinario de manera coherente, con reconocida competencia por los pacientes y otros sectores de la institución y las deficiencias estructurales en el servicio de atención a los pacientes inmunodeprimidos.

Conclusión: se encontró que hay una necesidad de estudios que se ocupan de las estructuras de atención en los servicios de trasplante de hígado y evaluar el impacto de la calidad de la esperanza de vida y la recuperación adecuada de las personas sometidas a un trasplante de hígado.

DESCRIPTORES: Trasplante de hígado. Equipo de atención al paciente. Flujo de trabajo.
\end{abstract}

\section{INTRODUCTION}

The transplantation of organs and tissues is consolidated worldwide as a therapeutic resource, used to cure diseases and improve the quality of life in individuals, affected by chronic pathologies. ${ }^{1}$ A study published in the United States in 2014 indicates that as of July 26 2013, there were 118,895 Americans waiting for organ transplants, among which 15,773 were waiting for liver transplants. ${ }^{2}$ World-wide experiments confirm the success of liver transplantation as a definitive cure for hepatocellular carcinoma, the seventh most common type of cancer worldwide since it allows the total removal of the tumor, ${ }^{3-4}$ and is also indicated for patients with decompensated cirrhosis and acute liver failure. ${ }^{5}$

The Brazilian public health system offers free and unrestricted access to services for the entire population who requires organs and tissues transplants. ${ }^{6}$ The country has one of the largest public transplant programs in the world with a policy based on Laws N. 9,434 / 1997 and N. 10,211 / 2001, which include free donation, beneficence towards recipients and non-maleficence in relation to living donors. ${ }^{7}$

Brazil is the second country in the world with the highest number of transplants performed per year. Of these transplants, more than $90 \%$ occur through public health system (Sistema unico de Saúde - SUS). On the other hand, the State of Santa Catarina occupies a prominent place in the national panorama and in 2011 was the Brazilian state which obtained the best index of effective organ donors per million population. This situation allowed the state to make history in Brazil, by being considered the first to exceed 25 donors per million people in the population. ${ }^{8}$

Liver transplantation has been used on a growing scale as therapy for terminal liver disease since the 1980s, after its approval by the National Health Institute (NHI), in theUnited States, in 1983. The success of the technique is indicated by statistics because from 1985 to 2011, about 100,000 people underwent liver transplantation, of which 30,000 had survived for more than five years; 16,000 more than ten years after the graft. ${ }^{9}$ Liver transplants have been performed in Brazil since 1968. ${ }^{1}$ As a result of the technological advances and improvements in surgical techniques, it was possible to optimize the time of surgery and recovery of patients undergoing liver transplantation. Twenty years ago, the surgery lasted between 17 and 24 hours and currently on average, it takes five hours. The postoperative recovery time also decreased, from 30 days to two weeks or in some cases ten days. ${ }^{10}$

The criteria used to distribute the organs in liver transplants are performed in the following order: blood typing, donor and recipient weight, and the Model for End-Stage Liver Disease (MELD) 9 . The MELD system is an index based on the severity of the disease and corresponds to a numerical value ranging from 6 to 40 . The most severe patients have higher MELDs and are prioritized in the allocation of liver grafts. ${ }^{10}$

In view of the notoriety of hepatic transplant therapy, based on consolidated public policies, and the interest of public health institutions in providing this service to the population, we ask: how is the flow of specialized care in liver transplantation structured in a University Hospital (HU) of the southern region of Brazil? Therefore, it is the objective of this study to describe the flow of a specialized service in the hepatic transplant service in a HU of the southern region of Brazil.

Thus, the accomplishment of a case study in a $\mathrm{HU}$, regarding the flow of specialized care in liver 
transplantation, becomes relevant to understand how this flow works and what are the weaknesses and difficulties which are faced. Through the visibility of the functioning of the flow, its potentialities and fragilities become noticeable, making the reflection and discussion about the improvements that can be made in health and nursing care possible.

\section{METHOD}

The present study is characterized as a qualitative research. The chosen approach was a single institutional case study, which proposed to explore a single phenomenon in a single location; liver transplantation in a HU. The case study, as a research strategy, is used in many situations to contribute to the knowledge that is possessed of individual, organizational, social, political and group phenomena.

The study was developed in a university hospital located in the southern region of Brazil. The HU is a fully public hospital, designed from the perspective of trinomial teaching, research and extension, and caters to the local community, visitors and tourists. ${ }^{12}$

In order to perform the data collection, we opted for documentary research techniques, semistructured interviews and direct observation. Data collection took place from November 2013 to February 2014. The entry into the field was made by the first contact with the nurse of the liver transplant service, who presented the service and the other professionals that compose it, as well as authorizing the stage of direct observation.

The documentary information came from medical records of three patients submitted for liver transplantation in the HU in order to identify the flow of care to these patients in the service. It is noteworthy that, for documentary research in medical records, patients were analyzed in the HU outpatient clinic, where they were invited to participate in the study and, on that occasion, granted their authorization by signing the Informed Consent Form (ICF)). Thus, three medical records were used to identify the flow of care to these patients in the service and the existing flows that in the nursing care in the institution. The instrument used to collect data from the medical records was prepared by the researcher and refers to the sector and professional that performed the patient care and aimed to confirm the flow of the patient in the service.

The interview phase consisted in getting to know the subjects of the team and their understandings about the liver transplantation treatment. The snowball methodological technique was used, which allowed each informant to indicate the next informant of the investigation, and so on. The workers who were on vacation leave, medical leave, and those who do not have a routine in the service, such as some members of the surgical team, who carry out activities in the institution according to the demand for organs and grafts, were excluded from the study.

The team involved in liver transplant care was composed of 24 medical professionals, doctors (12), nurses (seven), psychologist (one), social worker (one), physiotherapist (one), dietitian (one), biochemist (one) and dentist (one). However, this quantity can be added to other professionals who, indirectly, participate in a relevant way in the configuration of the patient care that requires liver transplantation, thus justifying the choice of snowball methodological technique.

Thus, semi-structured interviews were conducted with 11 professionals from the HU liver transplantation team, who were invited to participated in the study (through the snowball technique) and expressed their interest and accepted, through the ICF, to participate in the research, including one nutritionist, two physicians, a pharmacist, a physiotherapist, four nurses, one psychologist, and one social worker. To ensure the confidentiality of the information and the anonymity of the professionals, the participants involved in the study were identified by the letter " $\mathrm{P}$ " for participants, followed by an ascending number. This way of identifying was based on the fact that the team has unique representatives from some professional categories, and identifying their professions could lead to unnecessary expositions.

We used the semi-structured interview technique, guided by our own instrument developed by the researcher, with the following questions: 1) How does patient care for patients who undergo liver transplantation occur? How does the team organize the service? 2) How is patient care, for those who have had a liver transplant? How does the team organize the service? 3) How is patient care for those who had a liver transplant in relation to post-discharge hospital follow-up? How does the team organize the service? 4) What facilitating aspects do you identify in the care of the patient who will undergo or has undergone liver transplantation? 5) What aspects do you identify as barriers / difficulties in patient care, who will undergo or has undergone liver transplantation?

Direct observation consisted of observing the flow of care and the routines of the service. It was 
carried out by means of monitoring the operation of the service in full shifts, in five periods of six hours. These observations were performed in, consultations, procedures, patient orientation in the liver transplantation outpatient clinic and the surgical hospitalization unit, as well as in a meeting with all the staff that make up the service. To record the data, a field diary was drawn up, highlighting the day, time, sector and observed aspects.

The analysis of data was oriented by the analysis of thematic content. ${ }^{13}$ This method of analysis allows articulation with one of the analytical strategies of the case study, which aims to analyze the data of the study, constructing an explanation about the case. The development of the thematic content analysis was followed by the following steps: 1st step - Pre analysis: a complete transcription of the information recorded in the semi-structured interviews was commenced. After the transcriptions were inputted in a word program document, a comprehensive reading of the existing material and manual selection of the most particular speeches, was initiated in order to enrich the discussion based on the objectives of the study. The data recorded from the charts of the three patients, and the direct observation carried out in the five meetings permeated the selection of the speech extracts contained in the interviews, in the sense of confirming or confronting information which were brought by the research participants. 2nd stage - Exploration of the material: at this moment, the analysis process began where the contents of the speeches were distributed in three thematic categories; In this article, the thematic category "Flow of service in the service" was approached. $3^{\text {rd }}$ Stage - Treatment of results: at this stage, the thematic category, linking the content of the participants' information collected in the semi structured interviews, the records from the documents, and the observation with the study's presuppositions and the theoretical basis were all explored. ${ }^{11}$ The triangulation of the selected data was then performed.

In the present study, the ethical principles addressed in Resolution No. 466/12 of the National Health Council, which deals with the Regulating Guidelines and Norms for Research involving Human Subjects, were respected. ${ }^{14}$ The study was submitted for the consideration and approval of the Committee for Ethics in Research, in the Universidade Federal de Santa Catarina (UFSC) under record number 454,283 . The participants' confidentiality and anonymity were ensured, and documentary, interview and observational data were collected only after verbal and written authorization of the participants were obtained through their signatures in the ICF.

\section{RESULTS AND DISCUSSION}

To better illustrate the obtained results, through the methodological techniques used in the study, we chose to construct a thematic category, which addresses the flow of care itself, which made it possible to discuss the specificities existing in the service process of the specialized hepatic transplant service in the HU.

\section{Service flow}

By means of observation and interviews, the gastroenterology outpatient clinic was verified as the entrance door to the liver transplantation service, which serves referred primary care patients from all municipalities in the state of Santa Catarina. The flow of the service of the specialized service in hepatic transplantation of the HU follows the organizational model of actions and health services recommended by the Ministry of Health through the Networks of Attention to Health (RASs). The RASs aim to enhance the performance of the health system in terms of access, equity, clinical efficacy, health and economic efficiency, seeking to maintain horizontal relations between health care services and, in this structuring, SUS users search the Networks to seek health care attention and depend on the effectiveness of this articulation to have their needs met. ${ }^{15}$ The organ transplantation team is multi or interdisciplinary. ${ }^{16}$ As soon as medical consultations and examinations are performed, which fit the patient into the legal parameters in order to become a transplant candidate, professionals from different areas who make up the team perform their evaluation and then the candidate is placed on an organ waiting list. In the nursing consultation, the patient receives a manual from the $\mathrm{HU}$, containing information on how the transplant is performed and the necessary lifestyle changes after the surgery. The patient takes this material home, where he can share it with his family and in subsequent consultations he can ask any doubts he may have regarding the process. The decision of the transplant candidate is held in meetings with all members of the team:

After the surgeons' recommendation for transplant the evaluation process of the patient by the other members of the multi-professional team is started: nursing, physiotherapy, nutrition, dentistry, psychology, social work and blood bank (P9). 
A positive factor, reported by the study participants and evidenced in the direct observation, refers to the care performed by the multi-professional team in welcoming and guiding the patient who is a liver transplantation candidate. In the logic of the importance of the involvement of the different professionals in this process, studies ${ }^{5,17-18}$ emphasize that the patient's trajectory, from entering the organ waiting list, to performing the transplant, is permeated by a process of questioning and clinical, physical, behavioral and cultural evaluations, and the life of the patients, after the transplant, has implications with changes in their daily life and also that of their family. ${ }^{17}$

The research participants emphasize the importance of the existence of the service in the HU, since it is possible to continue the care after the diagnosis of the disease, establishing the transplant therapy with the team that performed it, without the need to refer the patient to another service:

Having this procedure here is a very good thing because we see our patients in bad conditions, they get to have good conditions, and they do not have to modify their treatment environment, to modify the people who take care of him in the same way they are so used to, because they have reached a stage where care longer exists in the service. But it is an achievement that, once started, it is very difficult for us to give up on continuing, however challenging the difficulties are (P4).

After the evaluation of the multi-professional team and the agreement that their name will be included on the transplant waiting list, the blood bank team also provides care to the patient and their relatives, in order to advise them regarding the need for blood donation from their support network, as well as for pre-transplantation examinations, according to the professional:

[...] the blood bank participates in the multidisciplinary team, because as it is a large surgery, a lot of blood components are usually used, so once you have the OK that the patient will be put on the list, the patient comes to us (P6).

The pre-transplantation consultation aims to verify the patient's condition to withstand surgery, ${ }^{18}$ the subsequent use of immunosuppressant and post-transplant care should be evaluated by dentists, nutritionists, psychologists, social workers and anesthesiologists before inclusion on the waiting list. Also, during the time the patient is on the waiting list, he/she should attend routine visits to the transplant group to assess their condition, where the MELD score is recalculated, and a change in transplant priority may occur in relation to other listed patients. ${ }^{19}$ Therefore, while the patient is on the waiting list, many patients will have severe complications and are admitted to the intensive care unit for treatment. These patients are temporarily unsuitable to undergo transplant surgery while on the waiting list. ${ }^{20}$

The professionals say that the home visit is a common practice of nursing professionals and social service which serves to understand the real social and sanitary conditions, as well as the patient's support network, and to better guide him in adapting to a new standard of care.

In the planning phase for the transplantation which is carried out with the patient, nurses and social workers perform home visits when they understand that there is a possibility of non-adherence to the necessary lifestyle changes, including housing, or to evaluate if the patient has financial conditions and emotional support network to adhere to the post-transplant treatment. Negative feedback from these professionals regarding the lack of sanitary conditions of the patient's dwelling can lead to the choice of the team to not perform the transplant and to opt for palliative treatments of the disease, understanding that there are social contraindications to the treatment. When it comes to patients who are candidates for liver transplantation, the importance of a home visit goes beyond the necessary observation, but a visit by a member of the transplantation team represents a way of life for the families, and this enhances them, reinforcing the idea of complicity between patient and team in relation to maintenance of posttransplant treatment. ${ }^{21}$

It is also pertinent to indicate that, insofar as liver transplantation comprises the possibility of donation occurring between living relatives and organ recipients, this can resize the importance of the relationship established between the transplantation team and the relatives, considering some specific aspects. In this perspective, a study, ${ }^{22}$ in comparing the resilience of living kidney or liver donors with community members, showed that although donors reflect more positive psychosocial characteristics than the general population, the kidney donor group was more resilient than the liver donor group. This fact is justified by the complexity of the liver donation operation, associated with increased morbidity and mortality after partial hepatectomy of the liver, triggering insecurity, stress and anxiety in the patient before and after partial donation of the liver. In addition, there is a possibility of coersion among the relatives of liver recipients, since, 
in this situation, the donors, necessarily, are family members; different from kidney donation.

Once listed, when the donor is diagnosed as brain dead, the doctor responsible for the team is advised by the transplant center and communicates to the nurse of the service, who then activates the surgical and anesthetic team, blood bank, nutrition, social work, physiotherapy, pharmacy and psychology. In addition, it performs the bed reservation in the ICU and in the surgical hospitalization unit. As well as this, the nurse contacts the patient and guides the patient to the hospital. Upon the arrival of the patient, hospital admission is performed as an emergency or elective hospitalization, according to the patient's arrival time at the hospital. One of the team doctors and the service nurse receives and refers the patient to the pre-surgical hospitalization and preparation process. Members from the psychology and social work service welcome the family of the future transplantee.

After the surgery, the patient is immediately transferred to the ICU, where he is received by the unit team, which has intensive care physicians, physiotherapists, nurses and nursing technicians trained to work with transplant patients. During the first twenty-four hours, the transplantee will have a nursing technician providing exclusive care to him/ her and, also, the immediate physiotherapy followup, aiming for early extubation and the reestablishment of the independent ventilatory standard. The nutritionist accompanies the patient from the im- mediate postoperative period, in order to establish the immediate onset of nutritional therapy.

After hepatic transplantation, the patient is referred to the Intensive Care Unit, where he/ she should remain for two to three days, if there are no complications. In the first 24 hours after surgery, a nursing technician, who underwent a training course in 2012, will provide exclusive care for this patient, taking turns with another equally qualified nursing technician every 12 hours (P9).

In a process of usual response to graft surgery for a new organ, the patient remains in the ICU for 48 hours and is then transferred to the surgical hospitalization unit, where he/she remains for one to two weeks or in a structured room designed for immunosuppressed patients. This room has an entrance with sink and materials such as aprons and masks, two beds, one for the patient and another for the companion, who is advised to remain with the patient at all times. The companion receives meals from the hospital's nutrition service and is also educated on the management guidelines for the newly transplanted patient. During hospitalization, patients and family members receive guidance about post-hospital care. Closer to the date of discharge, various professionals, mainly nursing, nutrition and pharmacy, pass on information about diet, glycemic control, blood pressure, weight and the continuous use of medications.

Each professional instituted a time of reassessment of the patient, as shown in the figure below, constructed from the information obtained in the interviews with the professionals.

\begin{tabular}{|c|c|c|c|c|c|c|c|c|c|c|c|c|c|c|c|c|c|c|c|c|}
\hline \multirow{10}{*}{ 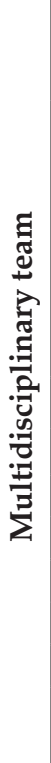 } & \multirow{3}{*}{$\begin{array}{c}\text { Professional } \\
\text { Doctor }\end{array}$} & \multirow{3}{*}{ 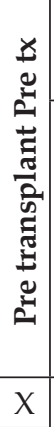 } & \multicolumn{4}{|c|}{$\begin{array}{c}\text { 1st } \\
\text { month }\end{array}$} & \multicolumn{3}{|c|}{$\begin{array}{l}\text { 2nd } \\
\text { month }\end{array}$} & \multicolumn{2}{|c|}{$\begin{array}{c}\text { 3rd } \\
\text { month }\end{array}$} & \multirow{2}{*}{ 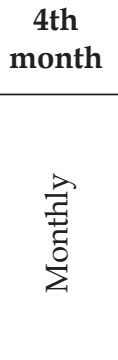 } & \multirow{2}{*}{ 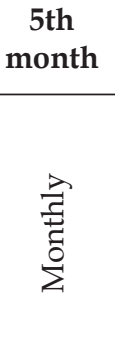 } & \multirow{2}{*}{$\begin{array}{c}\begin{array}{c}\text { 6th } \\
\text { month }\end{array} \\
\text { 吾 }\end{array}$} & \multirow[b]{2}{*}{ 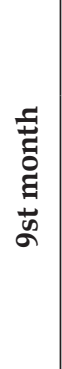 } & \multirow[b]{2}{*}{ 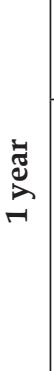 } & \multicolumn{4}{|c|}{ 2nd year } \\
\hline & & & $\begin{array}{l}\vec{v} \\
\stackrel{d}{d} \\
3 \\
\vec{n} \\
\vec{t}\end{array}$ & $\begin{array}{l}\breve{y} \\
\tilde{d} \\
3 \\
\bar{\Xi} \\
\tilde{J}\end{array}$ & 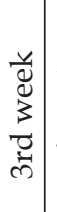 & 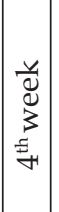 & . & & 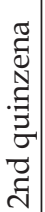 & 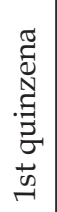 & 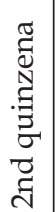 & & & & & & 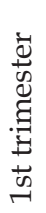 & 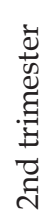 & 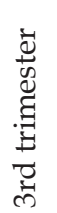 & 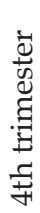 \\
\hline & & & $\mathrm{x}$ & $x$ & \multicolumn{2}{|c|}{$x$} & $x$ & $x$ & $x$ & $\mathrm{x}$ & $x$ & $X$ & $x$ & $x$ & & $x$ & $x$ & $x$ & $x$ & $x$ \\
\hline & Nurse & $x$ & & & & & $x$ & & & $x$ & & & & $x$ & & $x$ & & & & \\
\hline & Nutritionist & $\mathrm{x}$ & & & & & & & & $x$ & & & & $x$ & $x$ & $x$ & & & & \\
\hline & Pharmacist & $x$ & $x$ & $x$ & \multicolumn{2}{|c|}{$x$} & $\mathrm{x}$ & $x$ & $x$ & $\mathrm{x}$ & $x$ & & & & & & & & & \\
\hline & Phsyiotherapist & $X$ & & & & & & & & $x$ & & & & $x$ & & $x$ & & & & $x$ \\
\hline & Psychologist & $X$ & & & & & & & & & & & & & & $x$ & & & & \\
\hline & Social worker & $X$ & & & & & & & & & & & & & & & & & & \\
\hline & \multicolumn{20}{|c|}{$\begin{array}{l}\text { From the third year on, medical follow-up continues to be quarterly, semi-annual or annual. The other specialties } \\
\text { meet the demand identified by the medical professional. }\end{array}$} \\
\hline
\end{tabular}

Figure 1 - Periodicity of consultations with the professionals of the multidisciplinary team. Florianópolis, SC, Brazil, 2014 
Post discharge liver transplant follow up is seen by the HU service as a determinant of the success of the therapy and it is necessary that the transplanted patients receive outpatient followup for a long period, since there is a possibility of complications resulting from the procedure, such as rejection of the hepatic artery graft, ${ }^{3.23}$ as well as recurrence of the disease. ${ }^{17}$

Figure 1 shows the periodicity of post-transplant liver consultations, instituted by the professionals of the multi-professional team of the HU service. One study ${ }^{18}$ indicates that post-transplant consultation usually occurs every eigth to 15 days during the first two months. After this period, every month during the first year, and every three months thereafter. In evaluations, the adequate function of the liver graft is verified and short and long term complications are prevented. Consultations are of paramount importance to confirm adherence to treatment, patient's adaptation to the new lifestyle, changes in diet and physical exercise to prevent metabolic complications, and to encourage patients to reestablish family, social and labor activities.

Post-discharge hospital follow-up is considered to be as important as the transplant procedure, since it involves adapting to the new organ and a new lifestyle, with adequate housing, food and social living standards, routines of visits to the hospital and also the use of immunosuppressive medications. A study ${ }^{24}$ indicates that the transplant patient should be described, not only for the clinical characteristics, but also for the psychosocial characteristics, which are: 1) Physical / functional (for example, perceived health status, sleep quality, daytime drowsiness). 2) Psychological (eg, depression, stress). 3) Behavior (eg: adherence to medication, smoking, drug use, physical activity, sun protection). 4) Social (eg, work capacity / return to work). 5) Overall quality of life and the factors associated with health care and the level of adherence to the system (eg, trust in the transplant team) are relevant. In this way, despite its high cost, liver transplantation has been successful worldwide, justifying the necessary focus on improving social participation (among them active participation in the labor and leisure market) of transplant recipients. Therefore, nurses working on the transplant team should also consider ways to increase confidence and minimize the depressive symptoms of liver transplant recipients. ${ }^{16}$

Regarding the difficulties related to posttransplant follow-up, the professionals highlighted the structural and logistic issues related to the care of the transplanted patient. The lack of physical space to separate the transplanted patient from the other outpatients was evidenced at moments of direct observation of the flow of care in the service and highlighted by the professional:

[...] yes, there is no way an immediate post-transplant patient could be kept waiting there, so I think maybe we could have more outpatient days (P3).

In the study scenario, there are no resources to perform some specific imaging tests, and some blood components required to perform the surgery come from the blood bank of the State, since the HU blood bank does not have the technology necessary to process all types of blood components, such as filtered irradiated blood. Regarding the physical structure, there are limitations in the number of outpatient rooms which are equipped and available to attend the transplant patient. There is no place for immunosuppressed people to wait for care, and some transplanted patients choose to wait in the chapel, or even on the street, as not to be exposed to contamination that could trigger infection. This is a paradox that worries professionals, since people have often fully adhered to the guidelines, modifying their homes and their lifestyles, and because they need to do an examination or have a consultation they run the risk of contracting a disease due to inadequate care environment.

The following speech reinforces a gap, verified in the documentary analysis. That is, there are no records of the care which the professionals provide, and some information related to the transplant is stored in files in the liver transplantation service, separated from the patient's chart in the HU. [...] the greatest difficulties are structural, processing information. We still do not have an information technology system here in the HU, it's all manual, a lot of paper. The information is not real-time, it's all on paper, and you have to go there to see the paper. So you are not able, you have trouble making things happen right, in time, everything will be the other day, tomorrow (P7).

Regarding the structure required by the health institution, Ordinace GM N. 3407/199825 recommends that, in order to perform liver transplantation, the establishment must have an anesthesia team with experience in liver transplantation and in the care of patients with hepatic insufficiency; Nurses with proven experience with liver transplants; Laboratory of clinical analyzes with capacity to perform tests for differential diagnosis of liver diseases; Blood bank capable of meeting the need for large amounts of blood and blood products, including apheresis system; Blood infusion system with flow capacity up to 11 liters per minute; 
Blood coagulation monitoring system; Controlled and heated fluid infusion system; Extracorporeal circulation system with centrifugal pumps; Interventional radiology service with diagnostic and therapeutic resources in the vascular and bile duct areas; Hemodialysis system, including hemofiltra- tion; Endoscopy, ultrasound with directional flow meter (colored doppler) and computed tomography. In order to provide a better visibility of the path taken by professionals and patients in the liver transplantation service in $\mathrm{HU}$, a flow chart was elaborated, which is presented in figure 2.

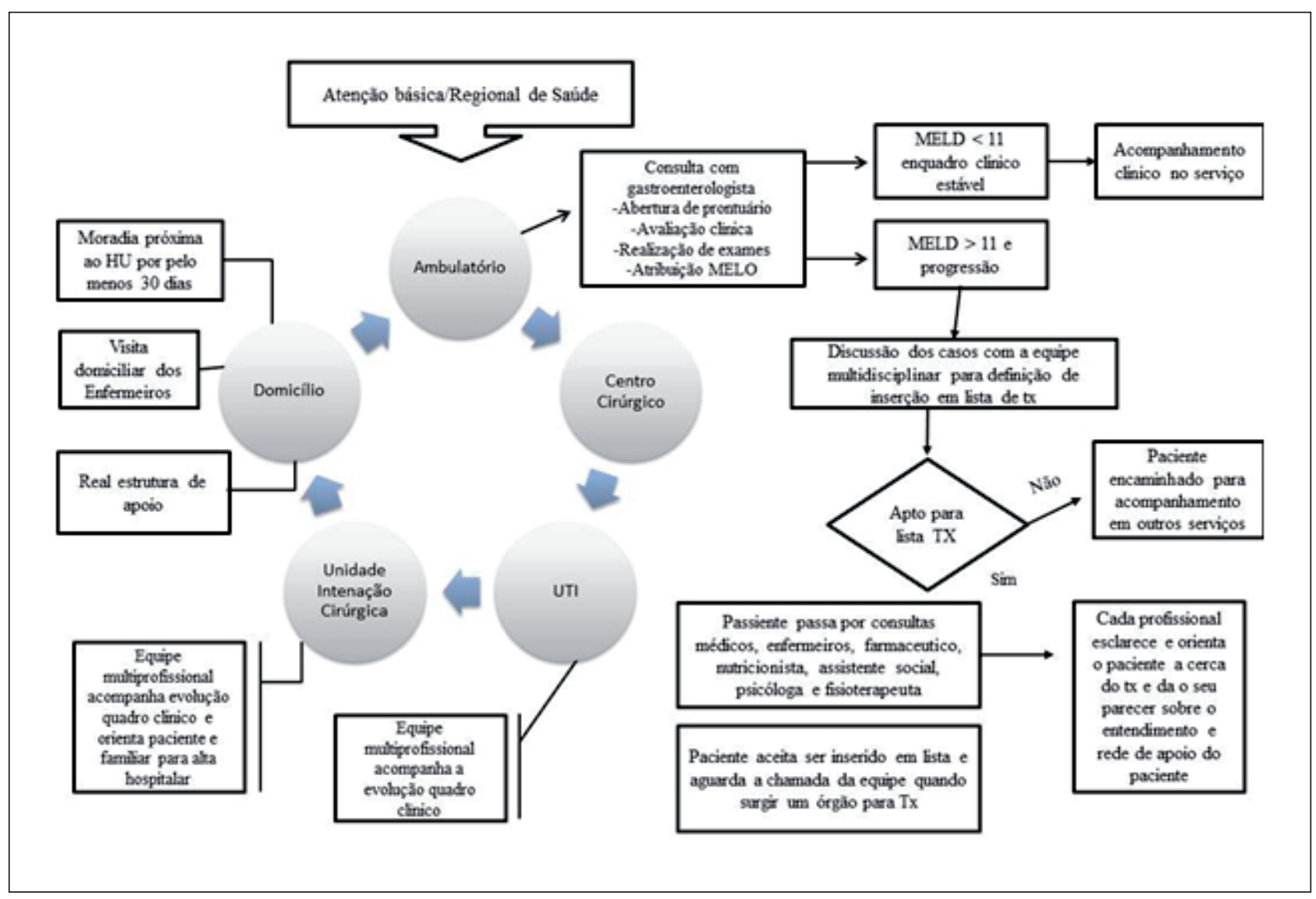

Figure 2 - Flow chart of the service in the liver transplant service of the HU. Florianópolis, SC, Brazil, 2014

\section{CONCLUSION}

From this study, it was found that the flow of care in the hepatic transplant service of the HU, even in non-ideal conditions, as emphasized at all times by the study participants and observed during the research, is successful in performing the proposed activities. From the first moment of the flow of care, in the gastroenterology outpatient clinic to the follow-up of the post-transplant patient, the multiprofessional team is competent to act in this care context, even with professionals not exclusively working in the transplant team. This fact makes it possible to infer that a multiprofessional team may be engaged in a project and act in a cohesive way, even though it is not solely directed to transplantation and, in that sense, it is concluded that the team needs to be competent, but not specific to a given follow-up service.

The greater fragility of the study scenario refers to the physical structure, where there is a need for improvements and adequate facilities to accommodate immunosuppressed patients, such as those transplanted, a condition that is seen as a potential complication to care, reported as high quality by patients and professionals.

In this regard, it should be noted that the service operates in a Brazilian university hospital, where in almost every area provides services to the community under non-ideal conditions, due to being included in a network of teaching hospitals, managed by financial funds, from the Ministry of Education, contemplating a paradox of inadequate 
investment in education to offer health services to the Brazilian population. In this sense, it is pointed out that, in addition to some university hospitals, there are many health institutions in Brazil that are deficient in physical structure and materials for organ and tissue transplantation.

Finally, there is a need for studies that address the structure and flow of care in liver transplantation services and to evaluate the impact of liver transplantation on life expectancy and the adequate recovery of people undergoing liver transplantation. Therefore, there is room for medium to longterm research, justifying the opening of more liver transplantation services in places that are still unattended, with health services with physical structures and human resources similar to university hospitals.

\section{REFERÊNCIAS}

1. Boin IFSF, Leonardi MI, Udo EY, Sevá-Pereira T, Stucchi RSB, Leonardi LS. Aplicação do escore MELD em pacientes submetidos a transplante de fígado: análise retrospectiva da sobrevida e dos fatores preditivos a curto e longo prazo. Arq Gastroenterol. 2008 Out-Dez; 45(4):275-83.

2. Chen HM, Shih FJ, Pan YJ, F.J. Shih FJ, Wang SS. The needs and expectations of overseas liver transplant recipients' families in Taiwan: across different transplantation stages.Transplant Proc. 2014 Apr; 46(3):782-4.

3. Mazzaferro V, Bhoori S, Sposito C, Bongini M, Langer M, Miceli R, et al. Milan criteria in liver transplantation for hepatocellular carcinoma: an evidence-based analysis of 15 years of experience. Liver Transpl. 2011 Oct; 17(10): S44-57.

4. Lucey MR, Terrault N, Ojo L, Hay JE, Neuberger J, Blumberg E, et al. Long-term management of the successful adult liver transplant: 2012 Practice Guideline by the American Association for the Study of Liver Diseases and the American Society of Transplantation. Liver Transpl. 2013;19 (1): 3-26.

5. Salvalaggio P, Afonso CR, Pereira LA, Ferraz-Neto B. Sistema MELD e a mortalidade em lista de espera para transplante de fígado em países em desenvolvimento: lições aprendidas em São Paulo. Einstein. 2012; 10(3):278-85.

6. Dalbem GG, Caregnato RCA. Doação de órgãos e tecidos para transplante: recusa das famílias. Texto Contexto Enferm. 2010; 19(4):728-35.

7. Associação Brasileira de Transplante (ABTO) [página na Internet]. São Paulo: SP; 2012. [cited 2012 Set 08]. Available from: www.abto.org.br

8. Lopes AD, Magalhães N. Muito além da cirurgia. Revista VEJA [Internet]. 2009 [cited Jun 2014]; Edição 2007. Avaliable from: http://veja.abril.com. br/080409/p_102.shtml
9. Universidade Federal de Santa Catarina (UFSC). Hospital Universitário. Diretoria de Enfermagem. Manual dos cuidados de enfermagem em pacientes candidatos a transplante hepático [Internet]. Florianópolis (SC); 2012 [cited 2014 May 13]. Available from: http://www.hu.ufsc.br/documentos/manual_ candidatos_transplante_hepatico.pdf

10. Hospital Sírio Libanês (HSL) [Internet]. São Paulo: SP; 2012. [cited 2013 Aug 15]. Available from: http://www.hospitalsiriolibanes.org.br/hospital/ especialidades/nucleo-avancado-figado/doencashepaticas/Paginas/transplante-hepatico.aspx

11. Yin RK. Estudo de caso: planejamento e métodos. $3^{\text {a }}$ ed. Porto Alegre: Bookman; 2010.

12. Ministério da Educação (BR) [Internet]. Relação dos Hospitais Universitários. Brasília: MS; 2013 [cited 2014 Jun 01]. Available from: http://portal.mec.gov.br/ index.php?Itemid $=512 \&$

13. Minayo MCS. Pesquisa Social: teoria, método e criatividade. 29a ed. Petrópolis: Vozes; 2010.

14. Ministério da Saúde (BR), Conselho Nacional de Saúde, Comissão Nacional de Ética em Pesquisa. Resolução n. 466 de 12 de dezembro de 2012: aprova diretrizes e normas regulamentadoras de pesquisa envolvendo seres humanos. Brasília: MS; 2012.

15. Ministério da Saúde (BR), Conselho Nacional de Saúde. Portaria n. 4.279 de 30 de dezembro de 2010: estabelece diretrizes para a organização da Rede de Atenção à Saúde no âmbito do Sistema Único de Saúde . Brasília: MS; 2010.

16. Weng LC, Huang HL, Wang YW, Lee WC, Chen KH, Yang TY. The effect of self-efficacy, depression and symptom distress on employmentstatus and leisure activities of liver transplant recipients.JAdvNurS. 2014Jul; 70(7), 1573-83.

17. Andrade AM, Castro EAB de, Soares TC, Santos KB dos. Vivências de adultos submetidos ao transplante de medula óssea autólogo. Cienc Cuid Saude. 2012 Abr-Jun; 11(2):267-74.

18. Mahmoudi H, Jafari P, Ghaffaripour S. Corresponding author:validation of the persian version of COOP/ WONCA functional health status charts in liver transplant candidates. ProgTranspl. 2014 Jun; 24(2):126-31.

19. Santos O, Marín J, Muñoz O, Mena A, Guzmán C, Hoyos $S$, et al. Transplante hepático em adultos: estado del arte. Rev Colomb Gastroenterol. 2012 JanMar; 27(1):21-31.

20. Hansen L, Yan Y, Rosenkranz SJ. The power of the liver transplant waiting list: a case presentation. AmJ Crit Care Nurses. 2014 Nov; 23(6):510-6.

21. Grossini MGF. Serviço social e transplante hepático pediátrico: o perfil sociocultural das famílias avaliadas e a intervenção do assistente social nas contraindicações sociais para o transplante. Rev HCPA. 2009; 29 (1):33-5. 
22. Rudow DLP, Lacoviello BM, Charney D. Resilience and personality traits among livingliver and kidney donors. Prog Transplant. 2014 Mar; 24(1):82-90.

23. González JTC, Bellido BG, Riera JV, Marente CLM, Gómez MG, Artacho SJM, et al. Study of liver transplant rejection in alcoholism-induced cirrhosis. Transplantation proceedings. Transplant Proc. 2013; 45 (10):3650-2.

24. De Geest S, Burkhalter H, Berben L, Bogert LB,
Denhaerynck K, Glass TR, et al. The Swiss transplant cohort study's framework for assessing lifelong psychosocialfactors in solid-organ Prog Transplant. 2013; 23(3):235-46.

25. Ministério da Saúde (BR), Conselho Nacional de Saúde. Portaria N. 3407 de 05 de agosto de 1998: aprova o Regulamento Técnico sobre as atividades de transplantes e dispõe sobre a Coordenação Nacional de Transplantes. Brasília: MS; 1998. 